\title{
The Lady of Gold: Sikandar Lodī's mother (c. 837/1433-922/1516) and the tomb attributed to her at Dholpur, Rajasthan ${ }^{1}$
}

\author{
Mehrdad Shokoohy \\ Professor Emeritus, University of Greenwich \\ prof.m.shokoohy@gmail.com
}

Natalie H. Shokoohy

Independent scholar

nshokoohy@aol.com

\begin{abstract}
Until the Mughal period historians of Muslim India hardly mention ladies, as it was considered discourteous, and even then only a handful of noble women were deemed worthy of mention. A secluded lady was of concern only to the man of the house. There was Sultan Radiya, Ilttutmish's daughter, who succeeded to the throne and enjoyed a degree of freedom during Turkish rule in India, but was killed, accused of an illicit relationship with a black slave. Nevertheless, many women's influence reached beyond the harem and their voices appear between the lines. One such woman was the Sharqī Sultan Muhammad's mother, Bībī Rājī̄, who played a significant role in the affairs of Jaunpur, but this article concerns another: Sultan Sikandar Lodī’s mother, known as Bībī Zarrīna (the Lady of Gold) who defied the Lodī nobility to put her son on the throne. Here we explore her story and study her tomb.

Keywords: Dholpur, Bayana, Rajasthan, Indo-Muslim architecture, Indian history, Sikandar Lodī, Arabic and Persian epigraphy, Islam
\end{abstract}

1 This study evolved from the authors' survey of the historic region of Bayana, the history of which was published in two parts in The Medieval History Journal (MHJ): M. and N. H. Shokoohy, "A history of Bayana - Part 1: from the Muslim conquest to the end of the Tughluq period", $M H J$ 7/2, 2004, 279-324, and "A history of Bayana - Part 2: from the rise of the Auhadīs to the early Mughal period (fifteenth-seventeenth centuries)", $M H J$ 8/2, 2005, 323-400. Studies of the monuments are published in Shokoohy and Shokoohy, "The architecture of Baha al-din Tughrul in the region of Bayana, Rajasthan", Muqarnas 4, 1987, 114-32 (repr. with fewer illustrations in Monica Juneja (ed.), Architecture of Mediaeval India: Forms, Contexts, Histories, New Delhi, 2001, 413-28); "Domestic dwellings in Muslim India: mediaeval house plans", Bulletin of the Asia Institute (BAI) 14, 2000, 89-110; "The chatri in Indian architecture: Persian wooden canopies materialised in stone", BAI 15, 2001, 129-50; "The mosques of Bayana, Rajasthan, and the emergence of a prototype for the mosques of the Mughals", MHJ 13/2, 2010, 153-97; and N.H. Shokoohy, "Waterworks of mediaeval Bayana, Rajasthan", BAI 18, 2004, 19-42. For the present article, translations from the Arabic and Persian are by the authors, unless stated otherwise. All photographs and survey drawings are also by the authors. 
It is said ${ }^{2}$ that in the days that Bahlūl Khān was Governor of that town (Sirhind or Sihrind) ${ }^{3}$ he had built outside the fort a mansion comparable to the heavenly paradise. Sometimes he resided there. In those vicinities lived a goldsmith who had a daughter called Hīmā, with a face like a tulip and hair the colour of musk; it happened that Bahlūl's eye fell upon her, he was enchanted. That beauty with moon-like face also gave her heart to him. When he sat on the royal throne he satisfied the wishes of her father and married her. One day that girl dreamt that the moon became detached from the sky and fell into her bosom. The next day she told her dream to King Bahlūl. When he asked its meaning from the interpreters and the Hindu priests $(k \bar{a} h i n \bar{a} n),{ }^{4}$ the hair-splitting interpreters opened the heart of the matter: that from the womb of this Queen of the World a son would be born who would gain the throne and would own the crown.

The Târīkh-i Shāh $\vec{\imath}$ s record of the name $\operatorname{Hin}^{-5}$ is curious as it is not a Muslim name, but is the Persian way of writing the Sanskrit hema (heman: gold, apparently a translation of the Persian zarrina), and this is perhaps what the non-Persian-speaking people called her. The Bībî̀'s name is recorded variously in different sources. At Dholpur, ${ }^{6}$ where she is believed to have been buried, she is known as Bībī Zarrīna (The Lady of Gold). Her name on her tomb is now partly eroded, but in 1885 Cunningham, ${ }^{7}$ who saw the inscription when it

2 Aḥmad Yādgār, Tārīkh-i Shāhī also Known as Tārīkh-i salātīn-i Afāghina: A History of the Sultāns of Delhi from the Time of Bahlül Lüdì (A.H. 855-894) to the entry of Emperor Akbar into Delhi in A.H. 964 (Pers.), ed. M. Hidayat Hosain (Bibliotheca Indica no. 257, Calcutta, 1939) (henceforth Tārīkh-i Shāhì), 17:

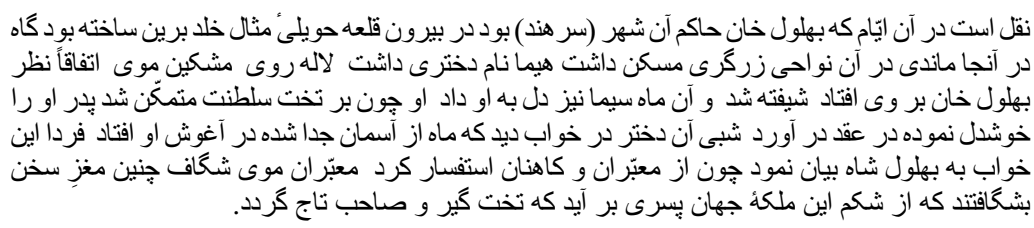

3 A historic fortified town situated at $30^{\circ} 22^{\prime} \mathrm{N}, 76^{\circ} 14^{\prime} \mathrm{E}$ in the Punjab on the way from Delhi to Lahore. It remained one of the main strongholds of Bahlūl, where he stayed from time to time even after he became King of Delhi.

4 An interesting reference to Brahmins being consulted for the interpretation of dreams. The Lodī era was an age of superstition and fascination with myths about magical events, with the historians reiterating current popular legends.

5 The published edition records the name of the goldsmith's daughter as Hīmā (هيم), but another manuscript (Tärīkh-i Shāhī, addenda, 385-6) gives it as that of the father. "Golden" would be a suitable honorific for either. In this manuscript the love story of Balban and the goldsmith's daughter is more flowery and elaborate. The text of the Tärīkh-i Shāhī, completed in 1054/1644-5, is peppered with non-Persian vernacular words. The main histories dealing with the Lodī period were written a generation or two after the fall of the Lodīs, but close enough in date to be based on the accounts of the surviving members of the Lodi court. Variations in names and accounts of events may derive from different narratives collected by the historians.

6 Situated at $26^{\circ} 42^{\prime} 0^{\prime \prime} \mathrm{N}, 77^{\circ} 54^{\prime} 0^{\prime \prime} \mathrm{E}$, north-west of Gwalior.

7 Alexander Cunningham, "Report of a tour in Eastern Rajputana in 1882-83", Archeological Survey of India Reports (henceforth ASIR), XX, 113-4. 
was better preserved, confirmed the name as Zarrīna. Historical sources, however, differ; her name, or perhaps honorific, is recorded in Firishta's Persian text as Zībā (beautiful), ${ }^{8}$ and in Briggs's translation as Zeina (Zīna, Zīnat: ornament, by extension also meaning elegance, beauty). ${ }^{9}$ Zinnat (زينة) could be a misspelling of Zarrīna (زرّينه) simply omitting the letter " $r$ ", and as she is known to have been the daughter of a goldsmith (zargar), ${ }^{10}$ while we may consider both texts to be slightly defective, both Zarrīna meaning "made of gold", and Zeina (Zīnat) meaning "ornament or jewellery" would be suitable for a goldsmith's daughter. In Islamic India it is unusual for the proper name of a woman, particularly a queen and the mother of a king, to be given in a historical text. In fact many of the sources omit mentioning the name of Sikandar's mother altogether. If she was referred to, it would be usual for a descriptive honorific to be employed, and in this case we may assume that all recorded names, including Zarrina would have been honorific. Those used all reflect appreciation of her beauty, and give revealing insights into her background and how the populace perceived the unseen mother of the king.

The son foretold by "the Hindu priests and the hair-splitting interpreters" was, of course, Sikandar, who apparently inherited his mother's looks: ${ }^{11}$

Sikandar Lodī ... in the days that he was a prince was called Nizām Khān. By the Almighty Lord he was adorned with exceeding elegance and beauty as though the painter of destiny had not drawn a face more pleasant than his on the tablet of life ... whoever saw him lost his heart to him.

The Tārīkh-i Shāhī continues with the affair of Shaikh Hasan's unrequited love for the Prince. Hasan, known as Shaikh Hasan Majzūb (the enchanted), was a grandson of Shaikh Abu'l-'Alā and a highly respected religious personage. ${ }^{12}$ To quash the rumours ${ }^{13}$ of the Shaikh's forbidden love, the young - probably

8 Muhammad Qāsim b. Hindū Shāh known as Firishta, Gulshan-i Ibrāhīmī known as Târìkh-i Firishta (2 vols with addenda bound together, Lucknow, 1864) (henceforth Firishta) (Pers.), I, 179. Firishta completed his history in 1015/1606-07.

9 John Briggs, 1829, in his translation of Firishta, History of the Rise of the Mahomedan Power in India till the year A.D. 1612 translated from the original Persian of Mahomed Kasim Ferishta (4 vols, London, 1829) I, 563, gives in brackets: "whose name was Zeina, the daughter of a goldsmith, but raised to the King's bed owing to her beauty". These words seem to have come from a manuscript other than the one he edited and published, where the name is again given as Zībā, and does not include the comment about her beauty. See, Ferishta, I, 329. Briggs, however, notes that he collated his material from several manuscripts.

10 In India goldsmiths were, and still are, also jewellers. They are not, of course, members of the nobility, but rank high among the merchant class.

11 Tärikh-i Shāhī, 29-30:

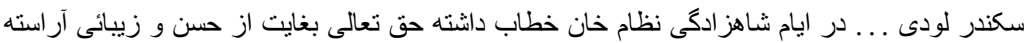

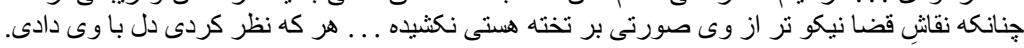

12 Shaikh 'Abd al-Haqq b. Saif al-dīn Muhaddith Dihlawī, Akhbār al-Akhyār fì asrār al-abrār (Delhi, 1332 [1914]) (Pers.), 289-90.

13 The rumours were apparently widespread and are reflected in many sources. See for example; Shaikh 'Abd al-Haqq, Akhbār al-Akhyār, 289: 
beardless ${ }^{14}$ - prince, in his own court and with others present, punished the Shaikh by putting his face into a hot brazier and then locking him up, although he was seen "miraculously" walking in the bazaar the next day.

Sikandar's mother was by no means a voiceless lady of the harem. Her son was not Bahlūl's eldest ${ }^{15}$ and had many adversaries. In the final days of the sultan's life she made sure that Sikandar remained in Delhi, safe from the machinations of the Lodi clan who wanted to eliminate him and had made the sultan summon him $^{16}$ to Itāwa. ${ }^{17}$ She heard that the most powerful emirs had resolved to make A zam Humāyūn, the sultan's grandson, the crown prince and that the ailing sultan had agreed. Colluding with 'Umar Khān ${ }^{18}$ - a prominent army commander who also held the position of vizier - she sent a messenger to Sikandar informing him that his life would be in danger if he came to the camp at Itāwa. Her son whiled away the time on the pretence of preparing for his journey, until Bahlūl died while en route to Delhi. ${ }^{19}$

$$
\text { از قصبه رايرى بود در دهلى سير ميكرد و با سلطان سكندر لودهى عشق ميباخت }
$$

"He was from the village of Rāprī, passing his time in Delhi and was in love with Sultan Sikandar Lodh $\vec{\imath}$.

'Abd'ullah, Tārīkh-i Dāwudī (Tārīkh-i-Da'udi) (Pers.), ed. Shaikh Abdur Rasheed (Aligarh: Aligarh Muslim University, 1969) (henceforth Tārìkh-i Dāwudī), 27 also mentions the persistent rumour. The work was completed in 983/1575-6, long after the other accounts.

14 Tārīkh-i Dāwudī, 35, and Tārikh-i Shāhī, 35, record that Sikandar was enthroned at the age of 18, but the Tärīkh-i Khān Jahānī (completed 1020/1611-12) and Firishta mention that when he became king he already had six sons, which is unlikely if he was only 18 , unless he was much older when his father died. See Khwāja Ni mat'ullāh b. Khwāja Habīb'ullāh al-Hirawī, Tārīkh-i Khān Jahān̄̄ wa makhzan-i Afghān̄̄ (Pers.), ed. Sayyid Muhammad Imām al-dīn (2 vols, Dacca: Asiatic Society of Pakistan no. 4, 1960) (henceforth Tārīkh-i Khān Jahānī), I, 171, and Firishta, I, 179. This is not implausible, as if he was born a few years after Bahlūl married his mother he could have been in his mid-thirties. Nizām al-dīn Ahmad, however, attributes these six sons as Bahlūl's and not Sikandar's. See Khwāja Nizām al-dīn Ahmad b. Muhammad Muqīm Hirawī, Tabaqāt-i Akbarī (Pers.) (3 vols, Bibliotheca Indica, no. 223, Calcutta: Asiatic Society of Bengal, 1927) (henceforth Tabaqāt-i Akbarî), I, 314.

$15 T \bar{a} r \bar{i} k h-i \operatorname{Da} w \bar{u} d \bar{l}, 12$, gives the name of the eldest son as Khwāja Bāyazīd, Sikandar as the second son and Bārbak Shāh as the third, but Firishta (see quotation below) mentions that Bārbak was the eldest living son, as Bāyazìd had apparently died during the life of the sultan.

16 Firishta, I, 178; also see Tārīkh-i Dāwūūì, 34-5; Tārīkh-i Khān Jahānī, I, 168.

17 Abu'l-Faḍl 'Allamī Fahhāmī b. Mubārak Nāgurī, Á'̄nn-i Akbarī (Pers.), H. Blochmann (ed.) (2 vols, Calcutta: Biblioteca Indica, no. 58, 1872) (henceforth $\bar{A}$ 'inn-i Akbarī ), I, 356, records Itāwa as a region with three towns: Itāwa, Rauprī and Hatkānat, under the royal province of Agra; for a translation see A'in-i-Akbari of Abul Fazl-i-'Allami, (3 vols, Calcutta, 1868-94) I, 183. The town and district are now known as Etah $\left(27^{\circ} 38^{\prime} \mathrm{N}, 78^{\circ} 40^{\prime} \mathrm{E}\right)$ in Uttar Pradesh, 207 kilometres (128 miles) from Delhi.

18 Firishta records his name as 'Umar Khān Shirwānī (or Sharwānī) but other sources, gives it as Sarwānī. See for example the Tārīkh-i Khān Jahān̄̄, I, 174-5; Tabaqāt-i Akbarī, I, 314. The Sarwānīs were an Afghan clan with a number of its members being nobles of Sikandar's court.

19 'Abd al-Qādir b. Mulūk Shāh Badāwūnī (Badaoni), Muntakhab al-tawārīkh (Pers.), Maulawī Ahmad 'Alī, Kabīr al-dīn Ahmad and William Nassau Lees (eds), (2 vols, Bibliotheca Indica, no. 51, Calcutta: Asiatic Society of Bengal, 1868) (henceforth 
On the death of Bahlūl in 894/1489 most nobles of the Lodī clan disapproved of Sikandar, but it was his mother, supported by Khān-i Khānān Farmulī - one of the most esteemed of Bahlūl's courtiers and responsible for Sikandar's upbringing $^{20}-$ who confronted the other nobles: ${ }^{21}$

When according to the Decree of the Unfathomable Most Powerful, King Bahlūl Lodī ${ }^{22}$ received the Mercy of the Lord during the mentioned journey, the emirs and pillars of the state gathered, opening the topics of discussion. Some favoured A zam Humāyūn, the grandson of the late king, but most preferred Bārbak Shāh, the eldest of the living sons, for king. At this time Sultan Sikandar's mother, Zībā by name, who was the daughter of a goldsmith and was accompanying the late king, called to the emirs from behind the curtain saying: "My son is the one who is fit to be king and would treat you well". 'İsā Khān Lodī, who was a nephew of Sultan Bahlūl, belittled her saying "The son of the daughter of a goldsmith is not fit to be a king, so says the well-known proverb that a carpenter's work will not come out right done by a monkey". ${ }^{23}$ Khān-i Khānān Farmulī, who was a powerful person, on hearing this retorted: "Yesterday the king died

Muntakhab al-tawārīkh), I, 312-3; (tr.) Asiatic Society of Bengal (3 vols, Biblioteca Indica no. 97), Calcutta, 1884-1925, I, 383, n. 3.

20 Tārīkh-i Shāhī, 19.

21 Firishta, I, 179:

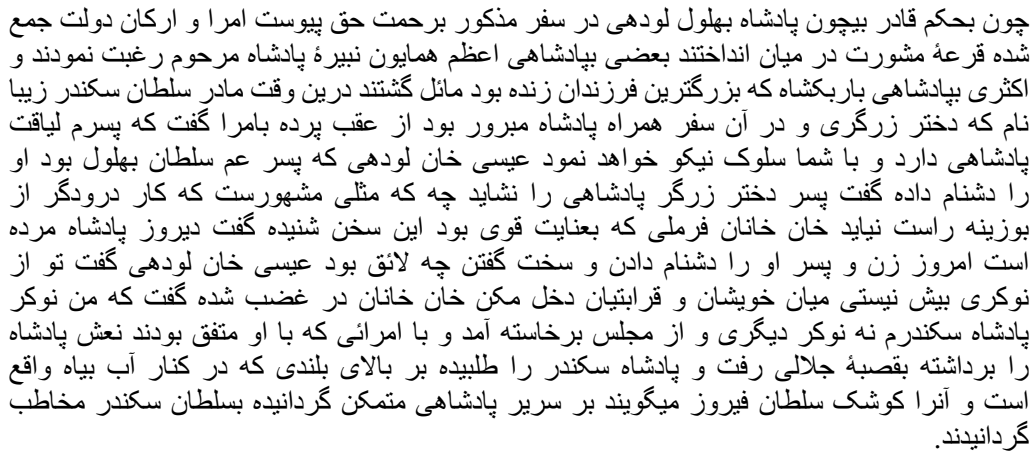

See also Tārīkh-i Shāhī, 35; Tabaqāt-i Akbarī, I, 314; Tārīkh-i Dāwūdī, 34-5; Tārīkh-i Khān Jahānī, I, 169-71. This last source mentions that the auspicious time for Sikandar's enthronement was calculated from the movement of the stars by Brahmin astrologers (brahmanān-i akhtar shinās).

22 Firishta systematically spells Lodī (لودى) as Lodhī (لودهى), but in our translation we have kept to the spelling given in all other sources.

23 A well-known Persian proverb referring to a story in the Kalīla wa Dimna, an Arabic and Persian translation of the Panchatantra. See 'Abd'ullāh b. al-Muqaffa', Kitāb Kalīla wa Dimna (Ar.) (Cairo, 1937) 96-7; Abu'l Ma'ālī Nașr'ullāh Munshī, Kalīla wa Dimna (Pers.), ed. Mujtaba Minuwi (Tehran, 1392 [2013]), 62. For a translation see Wyndham Knatchbull, Kalila and Dimna, the Fables of Bidpai (Oxford, 1819) 88-9. The proverb was immortalized by the twelfth-century Persian poet Nizāāī Ganjawī in his story of Khusrau and Shīrīn:

$$
\text { هوا بشكن كزو يارى نيايد كه از بوزينه نجارى نيايد }
$$


and today how can it be proper to use vilifying defamatory words against his wife and his son?" 'Īsā Khān Lodī replied: "You are no more than a servant! Do not interfere with the family and relatives!" Khān-i Khānān became angry; declaring: "I am the servant of King Sikandar and no one else" and left the assembly. He came to the emirs who were allied to him, took the king's corpse and went to the village of Jalālī, then sent for King Sikandar and put him on the royal throne on the heights by the River $\bar{A} b-i$ Bīyāh in the place called the Mansion of Sultān Fīrūz. ${ }^{24}$ They named him Sultān Sikandar.

Sikandar was enthroned on 17 Sha bān 894/16 April $1489^{25}$ and during his reign focussed on consolidating his sultanate and eliminating the vestiges of the Sharqīs, while being under constant threat from the south, particularly Gwalior. To achieve undisputed control, in 897 he finally put a permanent end to the semi-autonomous rulers of Bayana, and made Khān-i Khānān Farmuli governor of the region, with the aim of securing the border with Gwalior. $^{26}$ Khān-i Khānān kept the southern borders firm until his death in $c$. $906 / 1500-01$, when the sultan assigned Bayana ${ }^{27}$ to his two sons, but an uprising instigated by Manakdev among the Hindus forced these sons to retreat, and Sikandar took over Dholpur, rebuilding the fort in $910 / 1504 .^{28}$ A year later

which could be loosely translated as: "leave idle fancies aside, they bear no fruit, just as carpentry is no work for a monkey".

24 The mansion must have been one of Fīrūz Shāh Tughluq's hunting lodges built between Delhi and Itāwa. The area was one of his hunting grounds, as recorded in Shams-i Sirāj 'Afîf, Tārīkh-i Fìrūz Shāhī (Pers.), ed. Vilayat Husain (Calcutta, 1891), 497. His betterknown hunting lodge was Kushk-i Shikār near the village of Mīrtha in the Miyān Du Āb region, known for its Ashokan column (now on the Delhi Ridge) re-erected there by Fìrūz Shāh, see ibid., 313-4. Both of these mansions were built on the top of hills, presumably to provide panoramic views of the hunting grounds. Miyān Du Āb or Du Āb (Persian: between two rivers) was an area between the Ganges and the Jumna in the vicinity of Delhi spreading northward to include the regions of Sāmāna, Sālūra Mīrut (modern Meerut) and Mīrtha, see, for example, ibid., 313, 452; Diyā' al-dīn Barnī, Tārīkh-i Fìrūz Shāhī, ed. W.N. Lees, S. Ahmad Khan, Kabiru'd-Din (Biblioteca Indica no. 33, Calcutta, 1862) 468-9, 473; Yahyā b. Ahmad b. 'Abdullāh al-Sihrindī, Tārīkh-i Mubārak Shāhī (Pers.), ed. M. Hidayat Hosain (Calcutta, 1862) 146, 160, 165, 167.

25 Tārīkh-i Shāhī, 34-5; Tārīkh-i Khān Jahānī, I, 168-70; Tabaqāt-i Akbarī, I, 313-4. Tārīkh-i Dāwūid̄, 34, gives 7 Sha bān; Firishta, I, 179 only mentions the year.

26 Tārīkh-i Khān Jahānī, I, 174-5. The Tārīkh-i Shāhī, 36-7 mentions that after the conquest of Bayana 'İsā Khān was appointed governor but a bilingual inscription of Khān-i Khānān dated AH 901/ve 1553 and Saka Era 1418 (AD 1496) in Bayana confirms the account of the Tārīkh-i Khān Jahānī. The Sanskrit version of the inscription mentions Khān-i Khānān's father's name as Shaikh 'Imād of the House of Shaikh Muhammad and the Tabaqāt- $i$ Akbarī, I, 314 records Khān-i Khānān's name as Muhammad. For the full text of the inscription see M. Shokoohy, Rajasthan I, Corpus Inscriptionum Iranicarum, Part IV, Persian Inscriptions down to the Safavid Period, vol. XLIX, India: State of Rajasthan (Lund Humphries, distributor SOAS, London, 1986) (henceforth Rajasthan I), 29-32.

27 A strategic territory with a formidable fort situated at $26^{\circ} 55^{\prime} \mathrm{N}, 77^{\circ} 18^{\prime} \mathrm{E}$ in southeastern Rajasthan, 160 kilometres (100 miles) south of Delhi.

28 Tārīkh-i Khān Jahānī, I, 190-1. Also see Tabaqāt-i Akbarī, I, 324; Muntakhab al-tawārīkh, I, 318-9; (tr.) I, 419, n. 3, 420. 
Sikandar seized on the opportunity of campaigning against Gwalior, initially without complete success, causing him to set up camp in Bayana, where he toyed with the idea of making it his new capital, but in 911/1515-66 decided on Agra. ${ }^{29}$ From this time on Sikandar Lodī spent most of his time in Agra and in Dholpur, which had finally been carved out of the territory of Gwalior. Not only was control of Dholpur vital to keep Gwalior in check, but also it seems that the sultan favoured the town for his residence, ${ }^{30}$ and for many months at a time stayed there, building palaces, other buildings and gardens at every stage between Agra and Dholpur. ${ }^{31}$

During the sultan's extended stays in Dholpur his mother, the senior lady and authority in his harem, would have been residing with him, particularly when we consider that in younger days, travelling with her husband Bahlūl, she was not of a retiring disposition. It is, therefore, plausible to consider that she might have died in Dholpur, although as usual the histories are silent about the sultan's private life. For the last few centuries, and probably since the Lodi era, the tomb and mosque compound in the graveyard has been attributed to her and while there are other tombs of the Mughal period and a sizeable Mughal step-well nearby, probably from the time of Jahāngīr, the most impressive structure is that of Bībì Zarrīna, whose identity as the mother of Sikandar Lodī is also endorsed by Cunningham. ${ }^{32}$ The scale and elaborate design of the monument also indicates persuasively that it must belong to a noble lady.

There are a number of inscriptions in the complex, some carved in relief over the $m i h r a \bar{b} b$ s of the mosque, while eroded or intentionally obliterated, seem to be of a religious nature and might not have included dates, but the inscription of the tombstone of the Lady, again suffering from erosion and obscured by layers of whitewash, is slightly better preserved. ${ }^{33}$ What can be deciphered is, on the headstone, the beginning of Quran II, 255 (âyat al-kurs $\vec{l}$ ) continuing on the right side and with the end of the verse on the left side, followed by what seems to be Quran XXIII, 118: ${ }^{34}$

29 At the time a village in the territory of Bayana. Tārīkh-i Khān Jahānī, I, 194-6.

30 Tārīkh-i Khān Jahānī, I, 197.

31 Firishta, I, 185: آخره نا دهليور منزل بمنزل قصر و عمارات بنا نهاد. Also see Tārīkh-i Khān Jahānī, I, 208; Muntakhab al-tawārīkh, I, 321; tr, 423.

32 ASIR, XX, 113-4.

33 The inscriptions of the tomb are studied in full here for the first time. For earlier reports see Rajputana Gazetteer, I, Calcutta, 1879, 267; ASIR, XX: 113, pl. 37; J. Horovitz, EIM, 1909-10: no. 596; Annual Reports of Indian Epigraphy, 1963-64, no. D. 310; Z.A. Desai, Published Muslim Inscriptions of Rajasthan (Directorate of Archaeology and Museums, Government of Rajasthan, Jaipur, 1971), 56-7, no. 177; Rajasthan I, 34-5, pl. 35; M. Shokoohy and N.H. Shokoohy, "A history of Bayana - Part 2", 391, no. 16.

34 On the head of the tomb:

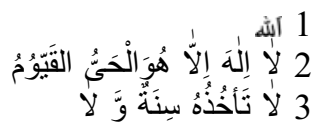

On the right side:

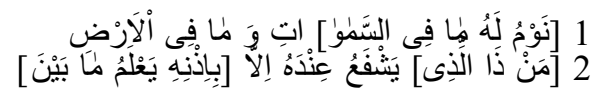

On the left side the rest of Quran 2: 255 followed by Quran 23: 118(?): 
On the foot of the tombstone is the historical record (Figure 1), badly damaged, and what remains from it is:

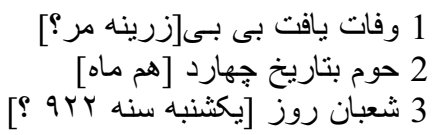

Departed Bībī [Zarrīna],

taken to the mercy (of God) on the date of the four[teenth of the month] of Sha bān on [Sunday in the year 922] (?).

The letters within square brackets are no longer preserved and reconstructed from a rendering - not an ink impression, which is more reliable for deciphering - by Cunningham (Figure 2), when the inscription was still in better condition, although we do not know to what extent it was preserved. At present no traces are left even of the name Zarrīna, but if Sikandar's mother was called Zībā, Zaina (pronounced Zinnat (زينة) in Persian), the letter represented as $r$ in Cunningham's rendering which makes the name zarrina may well have been the diacritic representing the vowel $a$ over the letter $z$, confusing the name with Zarrina. Zaina or Zinat are still current women's names in Iran and elsewhere. Nevertheless we should perhaps trust Cunningham and others, as well as the local population, for the name.

In Cunningham's rendering the figure for the decade is clearly close to the Arabic numeral two, making the date 922 ( 9 r $r$ ), but he reads the date as 942 $(9 \leqslant r)$ presumably to square up the reading of the date of the month with a year when that date fell on a Sunday. ${ }^{35}$ The date of the Bībī's death, however,

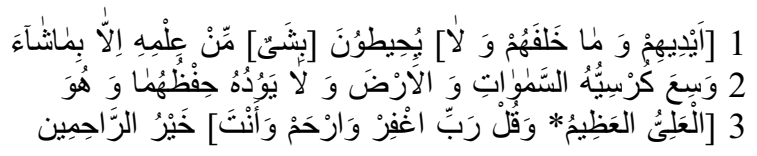

Ayat al-Kursī (the Throne Verse) is commonly carved on tombstones and occasionally on mosques. For an English version of this verse see A.J. Arberry, The Koran Interpreted (2 vols), London and New York, 1955, I, 65: "God: there is no god but He, the Living, the Everlasting, Slumber seizes Him not, neither sleep; to Him belongs all that is in the heavens and the earth. Who is there that shall intercede with Him save by His leave? He knows what lies before them and what is after them, and they comprehend not anything of His knowledge save such as He wills. His Throne comprises the heavens and earth; the preserving of them oppresses Him not; He is the All-high, the All-glorious", and for Quran, 23: 118 see Arberry, II: 45, “And say: 'My Lord, forgive and have mercy, for Thou art the best of the merciful"'.

35 Cunningham transcribes the day of the week as Sunday (يكثنبه), and the parts of the letters still preserved could correspond with his reading, but Thursday (ينجشنب) is also a possible reading. The day of the week as calculated mathematically does not necessarily correspond with the actual day of the week as perceived at the time, since the beginning of the Muslim lunar month derives from the confirmation of the observation of the crescent of the new moon, which may have been seen at different times or days in various places. 14 Sha ban 942 corresponds with Sunday 6 February 1536 and 14 Sha bān 922 with Thursday 15 or Friday 16 February 1516 (depending on different methods of calculation). In either case we should be cautious to take the day of the week as exact for a lunar (Hijra) 


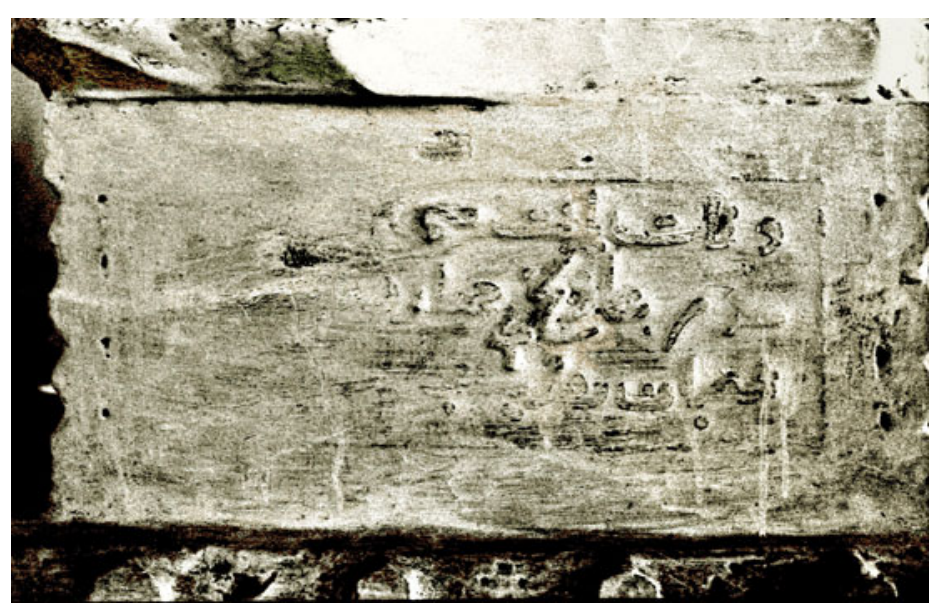

Figure 1. (Colour online) Dholpur, the historical inscription of the foot of the Tomb of Bībī Zarrīna. The eroded text bears part of her name and the date of her death, probably Sunday 14 Sha'bān 922/12 September 1516.

is noted in the Rajputana Gazetteer ${ }^{36}$ as 922 , presumably taken from this inscription. We can, therefore, safely assume that the reading of 922 is more reliable. If we accept this, she would have been in her eighties when she died. ${ }^{37}$

date. It should also borne in mind that 942 corresponds with the reign of Humāyūn and our calculation in the note below shows that if Bībī Zarrīna was indeed Sikandar's mother, at the time of her death she would have been unrealistically old. The authors have compared the mathematical calculations with many dated epigraphic records and have found discrepancies of up to three days between the day of the week recorded in inscriptions (including those of Bayana) as opposed to those calculated mathematically (see M. Shokoohy's review article: "Michael Mann, Hijri: a computer program to convert Hijri to Julian dates", BSOAS 55/2, 1992, 328-9).

36 Rajputana Gazetteer, I, 267 reports that the shrine was built in 944/1537-38 over the remains of "Mussummat Zurrina" (apparently for "the innocent Zarrīna") who died in 922. The shrine is likely to have been built soon after the death of the Bībī (if not by her during her lifetime), while 944 is far too late as it falls to the time of the Mughal emperor Humayūn and his struggles with Shīr Shāh Sūrī.

37 If we consider that Sikandar was enthroned in 894 at the age of eighteen, this would make the date of his conception nineteen years earlier in about 875 , but Bahlūl came to the throne in 855 , twenty years earlier. If Bahlūl married Sikandar's mother soon after he became king when she was 15-18 years old she would have been born in about 837 to 840 and in her eighties when she died. However, if we ignore the testament about Sikandar's age when he was enthroned and consider that he was born a few years after Bahlūl married his mother, let's say about 857 to 860 , he would have been in his midthirties when he was crowned and could have had six sons. His mother would have been younger when she gave birth, but would have still been born around our suggested date, and in her eighties at the time of her death. Our rough calculation again points out that the date of 922 for the Bībì's death is more acceptable and 942 unlikely as she would have been over 100 years old. 


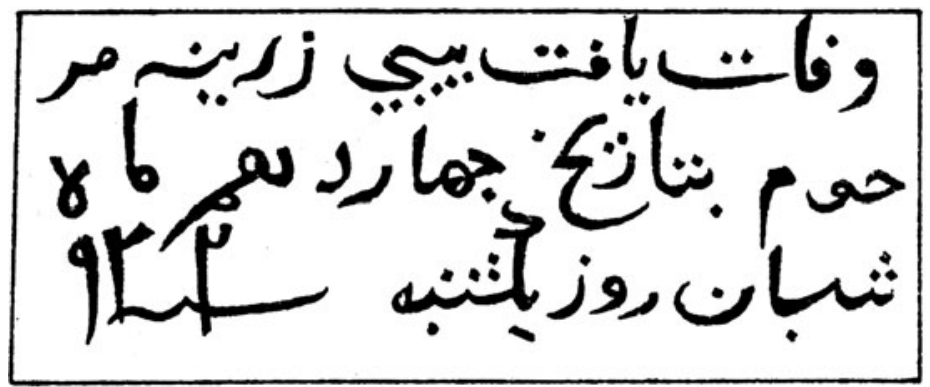

Figure 2. Cunningham's rendering of the inscription of the Tomb of Bībi Zarrina. The epitaph was in better condition when read by him $(A S I R, \mathrm{XX}$, 1885, pl. 37).

Sikandar himself died a year later and was buried in Delhi, ${ }^{38}$ in a tomb octagonal in plan with arches and domes much in the style of his predecessors, the Sayyids.

Dholpur, 35 miles $(56 \mathrm{~km})$ south of Agra and 20 miles $(32 \mathrm{~km})$ north-west of Gwalior was historically a small town in the territory of the Rajas of Gwalior, ${ }^{39}$ coming under Muslim control only at the time of Sikandar Lodī. The Bābūr-nāma mentions Sikandar's dam, forming a great lake, as well as a garden there, presumably from the time of the sultan, and that Bābur ordered a seat and four-pillared platform (talar, apparently a four-columned chatri $)$ to be carved out of solid rock on the east of the lake, and a mosque on the west. ${ }^{40}$ The $\bar{A}$ 'in-i Akbari records that when Agra was made the capital, Dholpur was one of the six districts which was taken out of the Bayana region and incorporated into the newly created region of Agra. ${ }^{41}$ With Muslim domination of the area, Dholpur's strategic importance increased, and while Sikandar Lodī built Agra as his capital, ongoing strife with Gwalior obliged him to reside in Dholpur

38 Survey in Friedrich Wetzel, Islamische Grabbauten in Indien (1918, reprinted Osnabrück, 1970) 83-5, Tomb 39, pls 46-51. Also see Tatsuro Yamamoto, Matsuo Ara and Tokifusa Tsukinowa, Delhi, Architectural Remains of the Delhi Sultanate Period (3 vols, Tokyo, 1967-70) I, 82, Tomb 79, pls 102 a and b. The tomb is in Lodi Park in Delhi, visited by many and often illustrated.

39 Dholpur is now little more than an hour from Agra on the modern Agra-Gwalior highway, but it was historically a small town with little strategic significance. Its name does not appear in the early Muslim histories, when in confrontation with the rajas of Gwalior the armies of Bahā al-dīn Tughrul encamped at Bayana rather than in Dholpur, in spite of its close proximity to Gwalior. The Auhadīs, the autonomous rulers of Bayana, also do not seem to have had jurisdiction over Dholpur. For the events concerning Dholpur and Muslim encounters with the Rajas of Gwalior see the authors' papers in M. and N. H, Shokoohy "A history of Bayana - Part 1", 291-2; and idem., "A history of Bayana Part 2", 359-60, 363-5.

40 A. S. Beveridge (tr.), The Bābur-nāma in English (Memoirs of Bābur) Translated from the Original Turki Text of Zahiru'd-dīn Muhammad Bābur Pādshāh Ghāzī, 2 vols, London, 1922, II, 606-7. For Babur's garden at Dholpur see also Elizabeth B. Moynihan, Paradise as a Garden: In Persia and Muhgal India, New York, 1979, 103-9.

41 A'’̄n-i Akbarī (Pers.), I, 356; (tr.), II, 103. 
for prolonged periods. ${ }^{42}$ The $\bar{A}$ ' $\bar{\imath}$ - $i$ Akbari also records that Dholpur had a brick fort on the bank of the Chanbal. ${ }^{43}$ The fort was indeed an old Hindu stronghold, which was apparently maintained and restored by the Lodīs and later reconstructed by Shīr Shāh Sūrī. Its ruins, named after Shīr Shāh, are now known as Shirgarh. ${ }^{44}$ Apart from the tomb of Bībī Zarrīna hardly any monument dating prior to the Mughal period has survived there, but the town and its immediate vicinity preserve a number of fine Mughal and post-Mughal structures, including the Khanpur Maḥal and Shāhī Tālāb, both known to have been built by Shāh Jahān.

\section{The mosque and tomb compound}

The Dholpur tomb and mosque, built on a high platform, are entirely of red sandstone ${ }^{45}$ and built in the trabeated structural method typical of architecture of the Bayana region. Unlike the Sayyid and Lodi buildings of Delhi, deriving from Tughluq architecture and often incorporating arcuate structures set partially on monolithic columns, in the Bayana region all major Lodī buildings, except one, and even those of the early Mughal period, are trabeate. ${ }^{46}$ In Delhi on the other hand, the tombs of the Lodīs are in the style of the Sayyids, ${ }^{47}$ octagonal chambers surrounded by an arcade with multiple chatris around the main dome, a form that appeared first in the tomb of Khān-i Jahān Tilangān̄i, ${ }^{48}$ and continued to be used by the Sūrīs and even in the early Mughal period, such as the tomb attributed to 'Alā al-dīn 'Ālam Shāh ${ }^{49}$ a brother of Sikandar Lodī and his Governor of Tijara, who later joined Bābur and died during the reign of Humāyūn, to one of the latest: the tomb of Adham Khān. ${ }^{50}$

The handsome and elaborate tomb of Bībī Zarrīna is a square building on the west of a rectangular courtyard facing the mosque (Figures 3 and 4). Although the platform could house a crypt, the absence of one indicates strongly that the tomb dates from the pre-Mughal era. A unifying design for the complex is

42 Tārīkh-i Khān Jahānī, I, 197.

$43 \bar{A}$ 'in-i Akbarī (Pers.), I, 443-4; also Á'in-i-Akbari of Abul Fazl-i-'Allami (tr.) (3 vols, vol. I translated by H. Blochmann, vols. II and III translated by H.S. Jarrett, Calcutta, 1868-94), II, 193-4.

44 Shirgarh, as with many other forts in India, remained in use in later generations, with consequent alterations.

45 The building of the tomb and the interior of the mosque are whitewashed, affecting their original appearance, but on the exterior of the mosque and the platform the red sandstone is left exposed.

46 See N.H. Shokoohy, "Waterworks of mediaeval Bayana, Rajasthan", BAI 18, 30-35; M. and N.H. Shokoohy, "The mosques of Bayana, Rajasthan", in particular 158-61.

47 For surveys of the tombs of the Mubārak Shāh Sayyid and Muhammad Shāh Sayyid see Wetzel, Islamische Grabbauten in Indien, 81-2, 85-6; also see Yamamoto et al., Delhi, Architectural Remains, I, 81-2, T. 77 - T. 78, a fresh survey of Muhammad Shāh Sayyid's tomb is also given in II, 75-96.

48 Survey in Yamamoto et al., Delhi, Architectural Remains, II, 136-9.

49 The tomb, over $34 \mathrm{~m}$ high and $38.5 \mathrm{~m}$ wide at ground level, is the largest of its kind. Survey in Cunningham, ASIR, XX, 115-6, pl. 27.

50 The son of Akbar's wet-nurse, who became one of his major commanders. Wetzel, Islamische Grabbauten in Indien, 89-92, figs 265-70. 


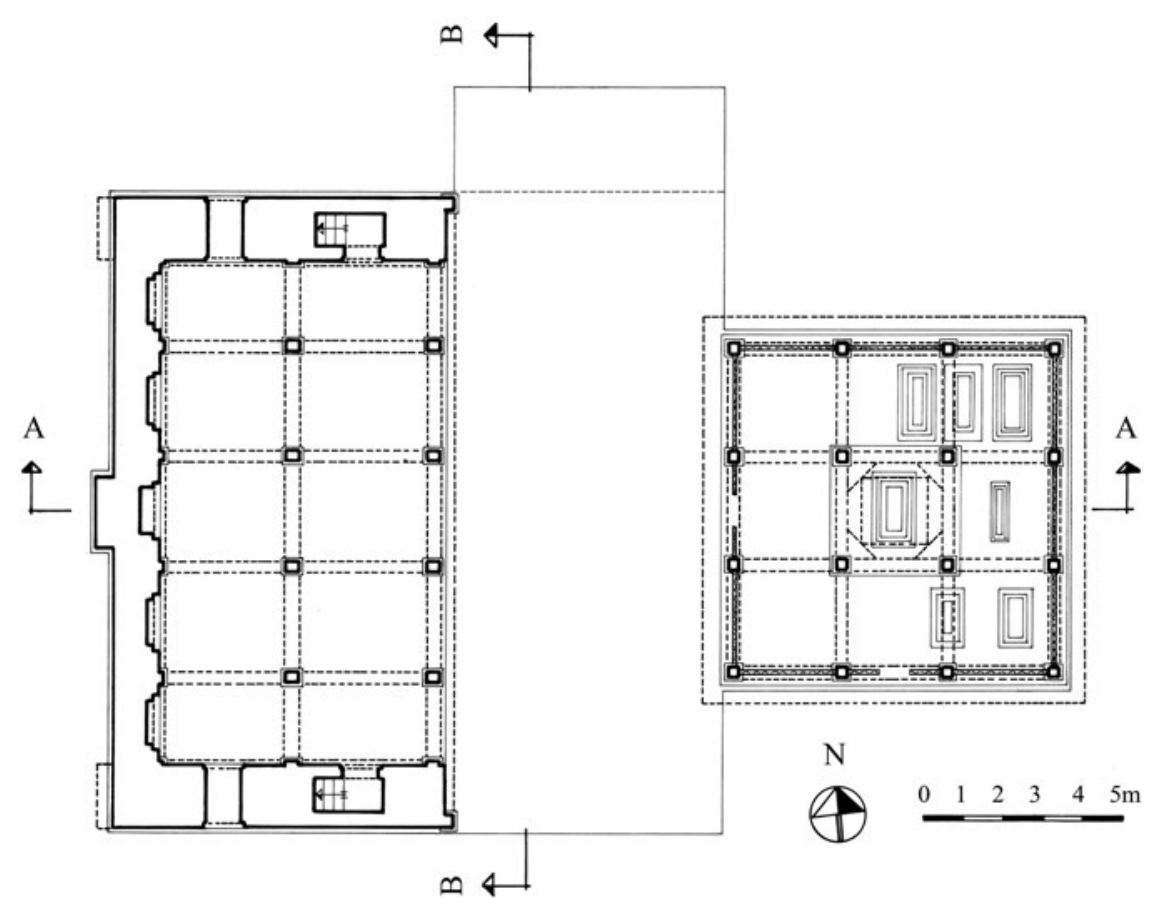

Figure 3. Mosque and tomb of Bībī Zarrīna, ground plan. The complex is set on a prominent platform, but has no crypt. The tomb of the Bībi is in the centre together with six other tombs at the east side of the tomb chamber. The area to the north of the dotted line in the courtyard seems to be a later addition.

expressed in the beam and bracket structure of the mosque and the tomb, but there are subtle differences in detail.

The compound is within a graveyard (Figure 5), and entered from the north, via steps and a modern gate with a semi-circular arch opening to the paved courtyard. ${ }^{51}$ The mausoleum is a square chamber consisting in plan of nine square units ${ }^{52}$ formed by 16 columns supporting a flat roof with slabs set directly on the lintels, except for the central unit where over the lintels are four triangular corner slabs and a further layer above formed of short lintels and triangular blocks, creating an octagon to support the flat roof slabs (Figures 3 and 6). The floor of the central unit, housing the tomb of the Bībi, is raised slightly in the form of a low platform decorated with mouldings. The columns are plain, but pierced stone panels $(j \bar{a} l \bar{\imath})$ are inserted between the

51 The long rectangular courtyard seems to have measured originally about $15.40 \mathrm{~m}$ long and $7.30 \mathrm{~m}$ wide, but was extended later by a few metres to the north, and additional new steps and entrance (not shown in our drawings) built.

52 The tomb measures about $8.30 \mathrm{~m}$ at each side and each of the internal units measures $2.37 \mathrm{~m}$ square. The column shafts are slightly over $1.60 \mathrm{~m}$ high and $0.29 \mathrm{~m}$ square in plan, resting on square base blocks and surmounted by usual bracket capitals. The total height from floor to the lintels is about $2.60 \mathrm{~m}$ and to ceiling about $2.90 \mathrm{~m}$. 

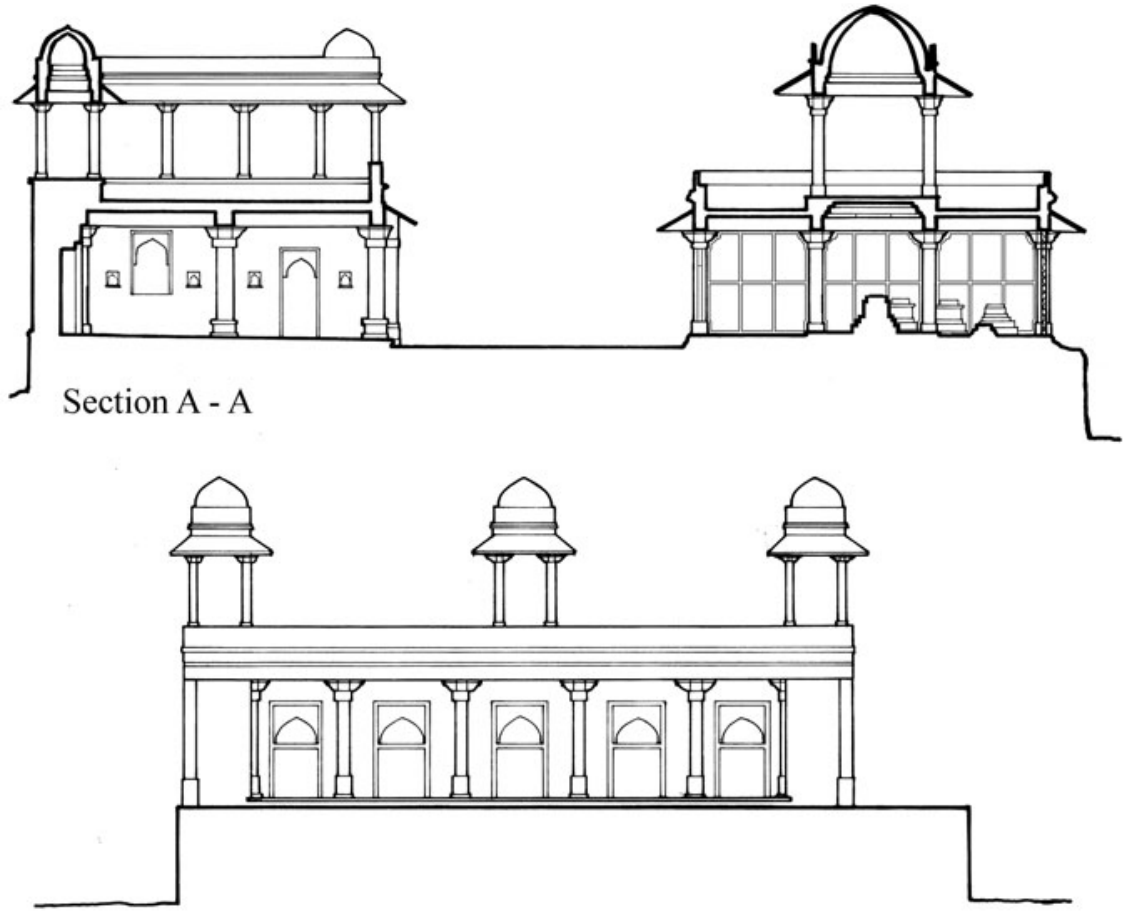

Section B - B

\begin{tabular}{llllll}
0 & 1 & 2 & 3 & 4 & $5 \mathrm{~m}$ \\
\hline
\end{tabular}

Figure 4. Mosque and tomb of Bībī Zarrīna, transverse section A-A through mosque and tomb; section B-B through courtyard, showing elevation of mosque.

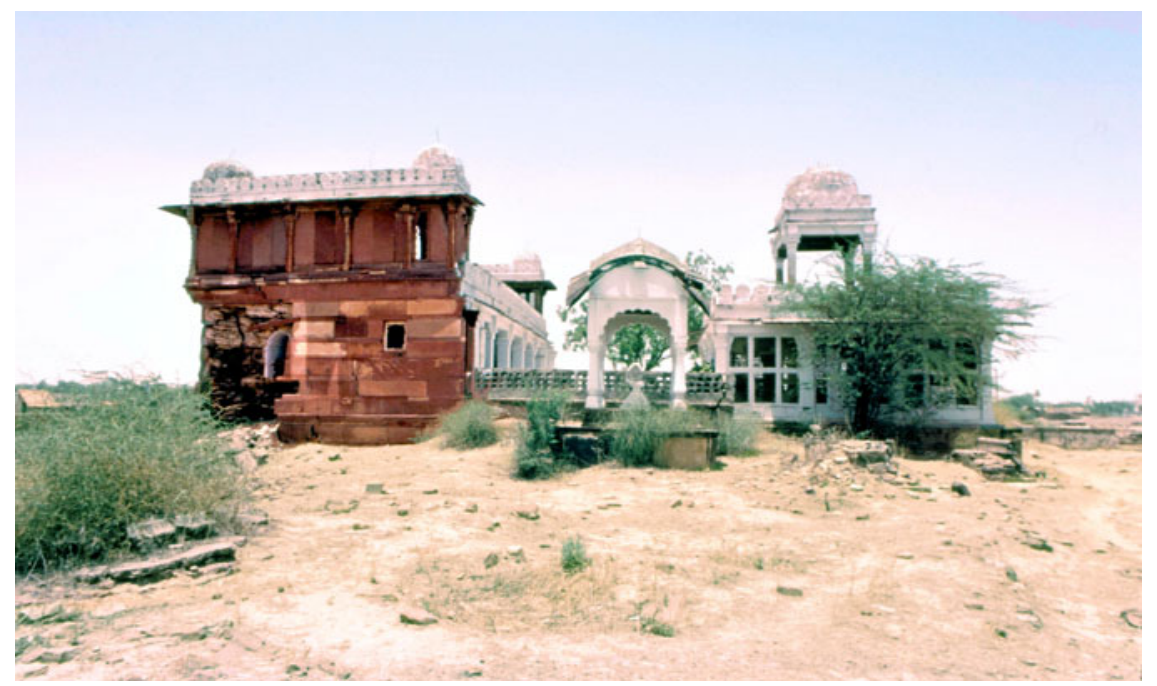

Figure 5. (Colour online) Mosque and tomb of Bībī Zarrīna, southern façade. The severely dilapidated rear wall of the mosque can be seen on the left. The tomb in the foreground with a "Bengali" roof dates from the late or post-Mughal era. 


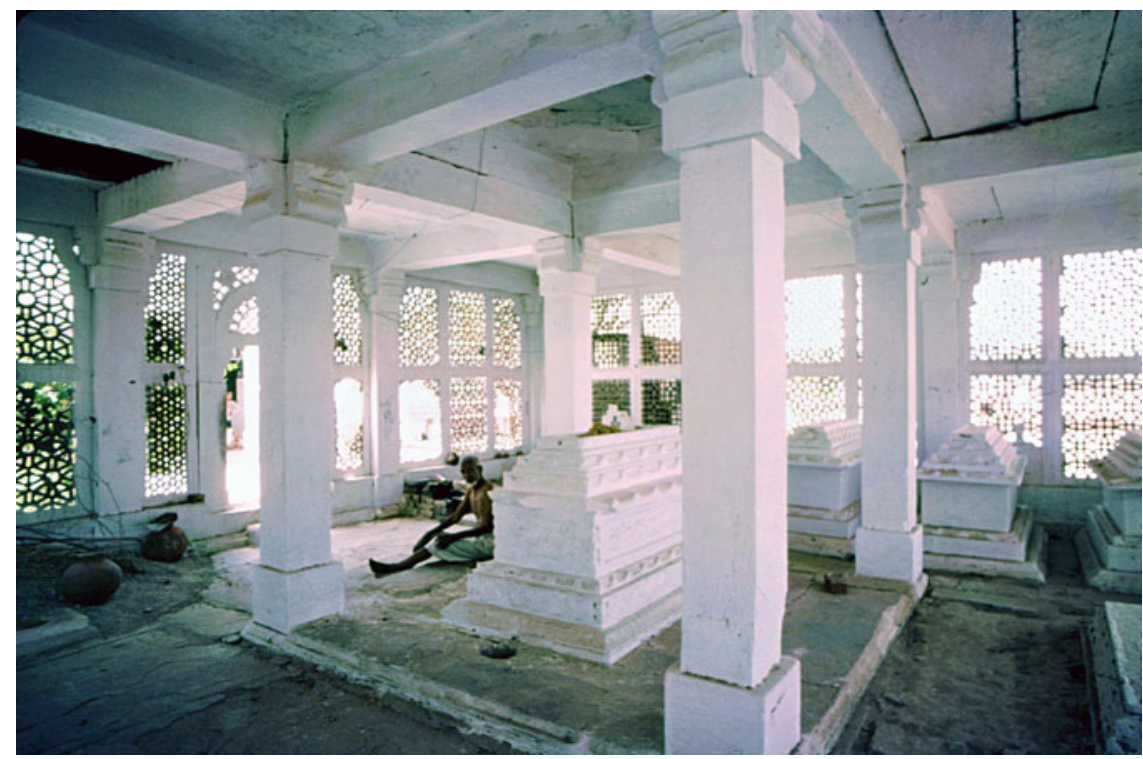

Figure 6. (Colour online) Tomb of Bībī Zarrīna, interior. View looking northwest showing the fine pierced stonework (now whitewashed) surrounding the cenotaph, and the raised roof over the Bībī's tomb.

exterior columns. The jāli screens are divided into six panels of almost the same size, except the middle of the western and southern sides where doors open to the tomb, each with an arch above, carved on a single panel as delicate pierced work, flanked by jāli panels. A variety of interlaced patterns are employed in the carved screens, giving a particular charm to the interior when light penetrates the screens and shadows of the patterns fall on the floor and the tombs.

In the middle of the building the tombstone of the Bībī (Figures 6 and 7) is in the form of a grand solid sarcophagus in several registers standing on a base with a cyma recta profile embellished with lotus leaf motifs, an ancient Indian pattern, also employed in Muslim buildings, but which hardly appears in Mughal architecture. This is another indication that the tomb is pre-Mughal. Above this base is a long and narrow register decorated with an interlaced pointed arch pattern, but many layers of whitewash make this and other carvings hardly visible. The register is topped with a row of triangular mouldings, probably a highly stylized reminiscence of the vajramastaka, which adorned the parapets of ancient temples. The middle block bears the already noted Quranic and historical inscriptions and the top two registers are stepped and have the same row of triangular ornament and are topped with a flat slab. There are six other tombs in the chamber, three similar in form to that of the Bībī, but slightly smaller and less elaborate. While none of the other tombs bear historical inscriptions, they must belong to her relatives. The elaborate form of the sarcophagi is not specific to these tombs and is seen in many of the more ornate tombstones of the Bayana region. Two of 


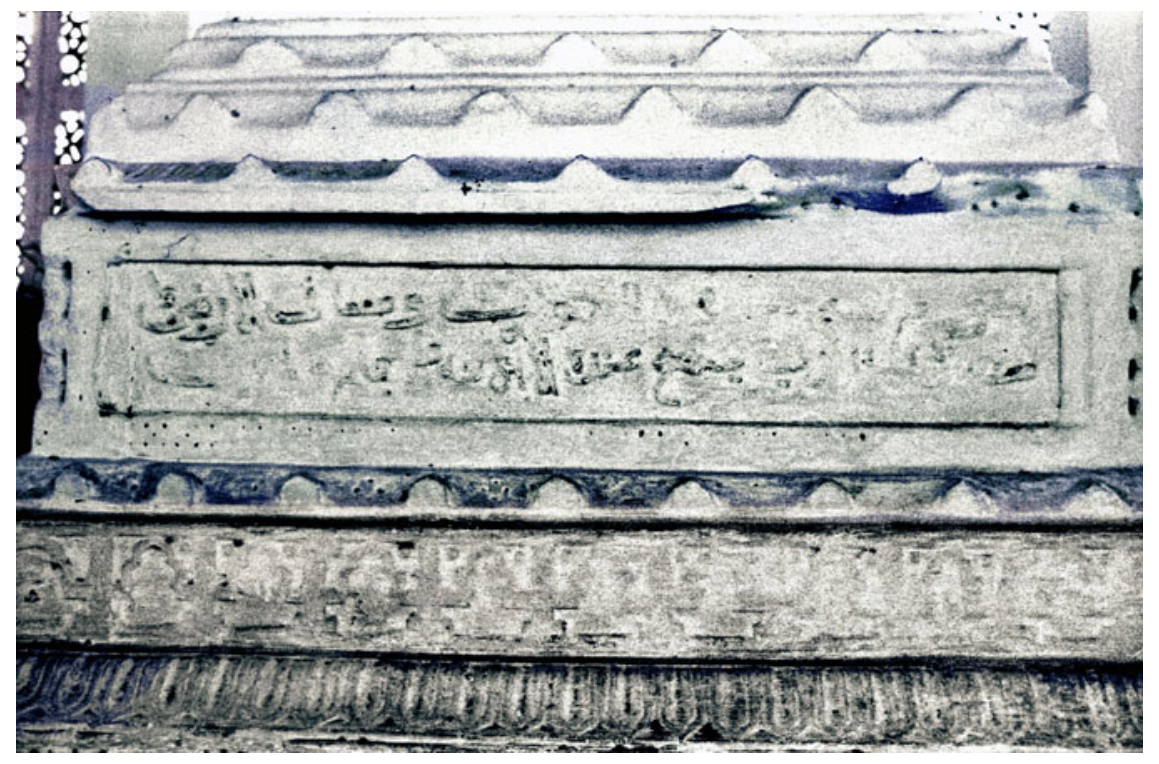

Figure 7. (Colour online) The sarcophagus of Bībī Zarrīna. View of the right side showing courses of decoration including the lotus leaf motif on the lower register and a course of lobed arches below the inscription which bears part of the Throne Verse ( $\bar{A}$ yat al-Kurs $\bar{\imath})$ of the Quran. Above the inscribed panels are rows of triangular motifs.

particular relevance here are of ladies, both in Hindaun (a historic town near Dholpur): that of Bībî Khadīja ${ }^{53}$ and of Bībì Rāsūlī. ${ }^{54}$

On the outside, the narrow columns and even thinner screens, give a sense of lightness to the well-proportioned chamber (Figure 8). At roof level the parapet above the eaves consists of two string courses, the lower carved with interlaced lobed arches within each of which is a bell-shaped floral motif. A simplified form of this motif is repeated on the narrower upper course. Above the parapet the crenulations, each carved on a separate panel, are in the form of a solid arch with a wide border and a central rosette. The most prominent feature on the exterior is a four-columned domed pavilion or chatri set on on a raised platform over the central unit of the structure (Figure 9).

There are precedents for chatīs on the roofs of buildings. Although colonnaded structures appear in Hindu architecture, chatrīs on roofs seem to derive from Iranian and Central Asian wooden canopies, often covered with textiles and illustrated in many Persian miniatures. The existence of such canopies in

53 The lady died on 15 Rajab 913/20 November 1507, her tomb is in the middle of an eightcolumned chatri, a form popular in the region, see Rajasthan I, 43-4, pl. 42. It attests to the presence of inscribed tombs of noble women of the period, less elaborate, of course, than tombs of royalty.

54 Her epitaph dated 25 Ramaḍān 846/27 January 1443 is now lying detached in the graveyard, but belonged to a tomb of the type common during the independent rule of the Auhadī Khāns. See Rajasthan I, 44, pl. 43 b. 


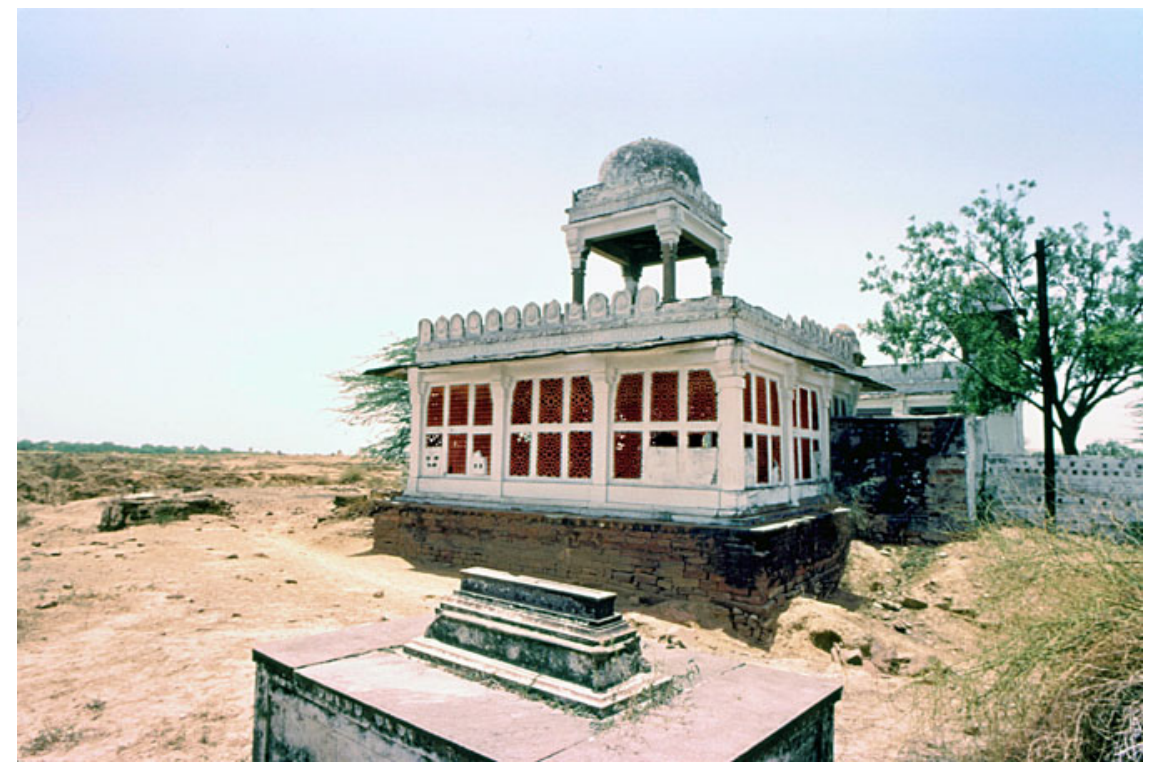

Figure 8. (Colour online) Tomb and mosque of Bībī Zarrīna, view looking south-west. The central chatri stands over the tomb. The compound is designed in such a way that each structure stands on its own and does not conflict with the other; as a result from the east the tomb stands alone and the mosque can hardly be seen in the background.

the early Sultanate period is recorded by Ibn Battuta, and the sockets of probable wooden supporting columns have survived on the roof of the Bijai Mandal, ${ }^{55}$ the palace of Muhammad ibn Tughluq in Delhi. The feature, transformed into stone, appears at least from the time of Fīrūz Shāh Tughluq; an early example in Delhi is over the mosque at Qadam Sharif, ${ }^{56}$ but they also appear on the roofs of L'al Mahal, ${ }^{57}$ Jahāz Mahal, ${ }^{58}$ and on the corners of the platform of the tomb of Daryā Khān Lohānī. ${ }^{59}$ However, a better example, near Dholpur, is the tomb known as Bare Kamar outside Bayana. ${ }^{60}$

In the tomb of Bībī Zarrīna the design is expressed not in the intricate detail, but in the boldness of the structural form. Nevertheless, the column shafts, octagonal

55 For survey see Annual Progress Report of the Superintendent, Muhammadan and British Monuments Northern Circle (ASINC), 1914, 39-40, pl. 25; Anthony Welch and Howard Crane, "The Tughluqs: master builders of the Delhi sultanate", Muqarnas, I, 1983, 14850. For a full discussion on chatrīs and their precedents, see M. and N.H. Shokoohy, "The chatrī in Indian architecture", 129-50 (Bijai Mandal, 177-8, 140, figs 15-6).

56 Yamamoto et al., Delhi, Architectural Remains, I, 56, M. 21.

57 Yamamoto et al., Delhi, Architectural Remains, I, 104-5, O. 11.

58 Yamamoto et al., Delhi, Architectural Remains, I, 106, O. 22.

59 Yamamoto et al., Delhi, Architectural Remains, I, 85, T.100; survey in II, 141-2; here the chatrīs, while above ground level are not actually on the roof, and the main central structure no longer exists.

60 BAI 15, 2001, 136-9, figs 13-4. 


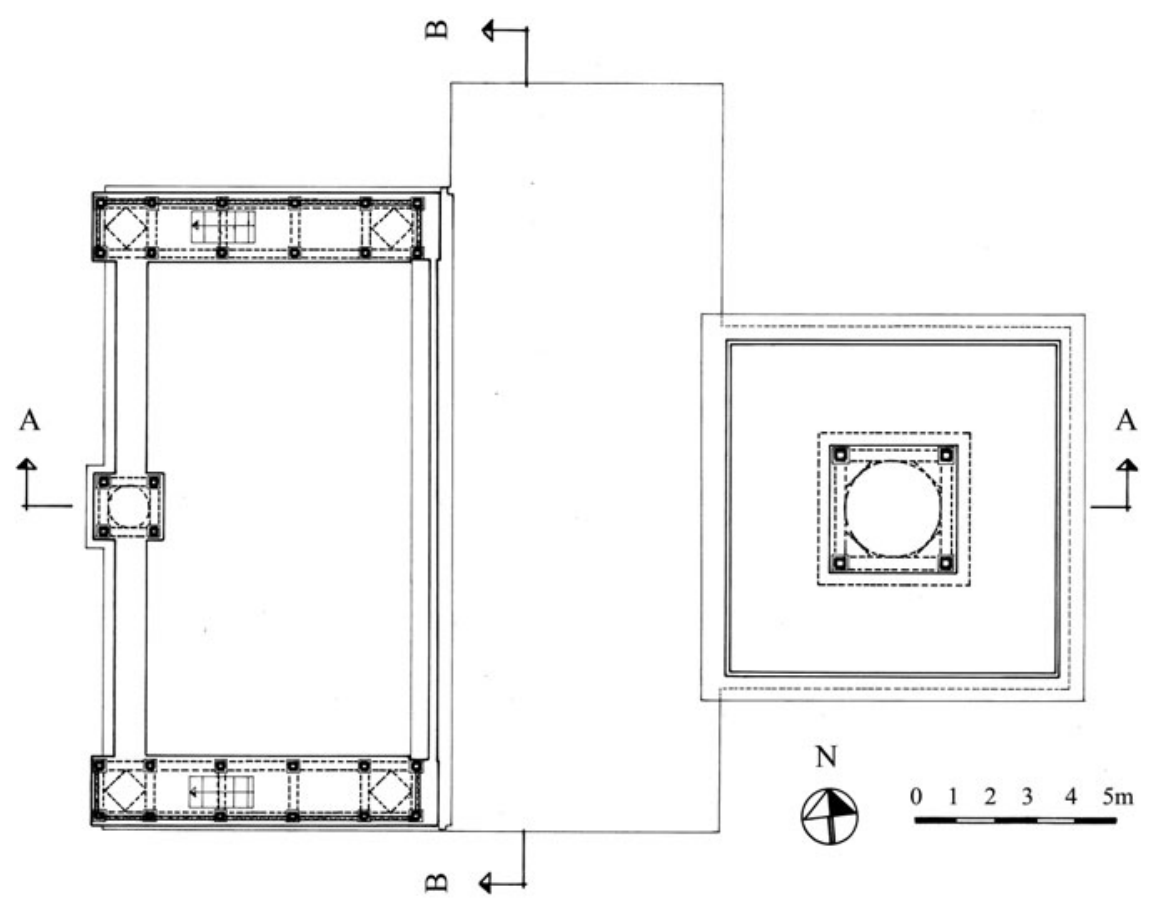

Figure 9. Tomb and mosque of Bībī Zarrīna, plan at roof level. The unusual roof colonnades with four domes and the chatrī over the central mihrāb echo the central chatri of the tomb.

in the middle and square at each end, stand on cubic bases and footings with cyma recta profile. The shafts are of a type seen commonly in Bayana and other towns of its region. The crenulations of the chatri, although similar in shape and proportion to those of the tomb, are not individually formed, but are carved on four panels, each set on one face, a treatment repeated in many chatris of the region.

Unlike the light structure of the tomb, the mosque, set at the west of the courtyard, has solid walls about $1.60 \mathrm{~m}$ thick, contrasting with the mausoleum from outside (Figures 10 and 12). The mosque is a simple prayer hall, two aisles deep and five bays wide, with the two side bays narrower than the rest (Figures 3 and 4). ${ }^{61}$ The column shafts are rectangular in plan, but the size of the narrow sides facing the courtyard corresponds with those of the tomb, retaining a fine aesthetic balance between the two structures while preserving contrast. On the qibla wall (facing the direction of Mecca) are five mihrā bs (prayer niches), with pointed arches, resembling the pierced stone arch-forms above the entrance of the mausoleum, but built in solid stone (Figure 11). Nevertheless, a balance harmonizing with the lattices of the $j \bar{a} l \bar{l}$ work of the tomb is maintained by the inclusion of interlaced foliated fringes

61 The prayer hall measures about $15.40 \times 9 \mathrm{~m}$ on the exterior. The column shafts measure $0.40 \times 0.29 \mathrm{~m}$ and $0.29 \times 0.29 \mathrm{~m}$ in plan, and the total height of columns corresponds with those of the tomb. The aisles measure $3.13 \mathrm{~m}$ wide and the three middle bays $4.42 \mathrm{~m}$ on average with the side bays $1.90 \mathrm{~m}$ wide. 


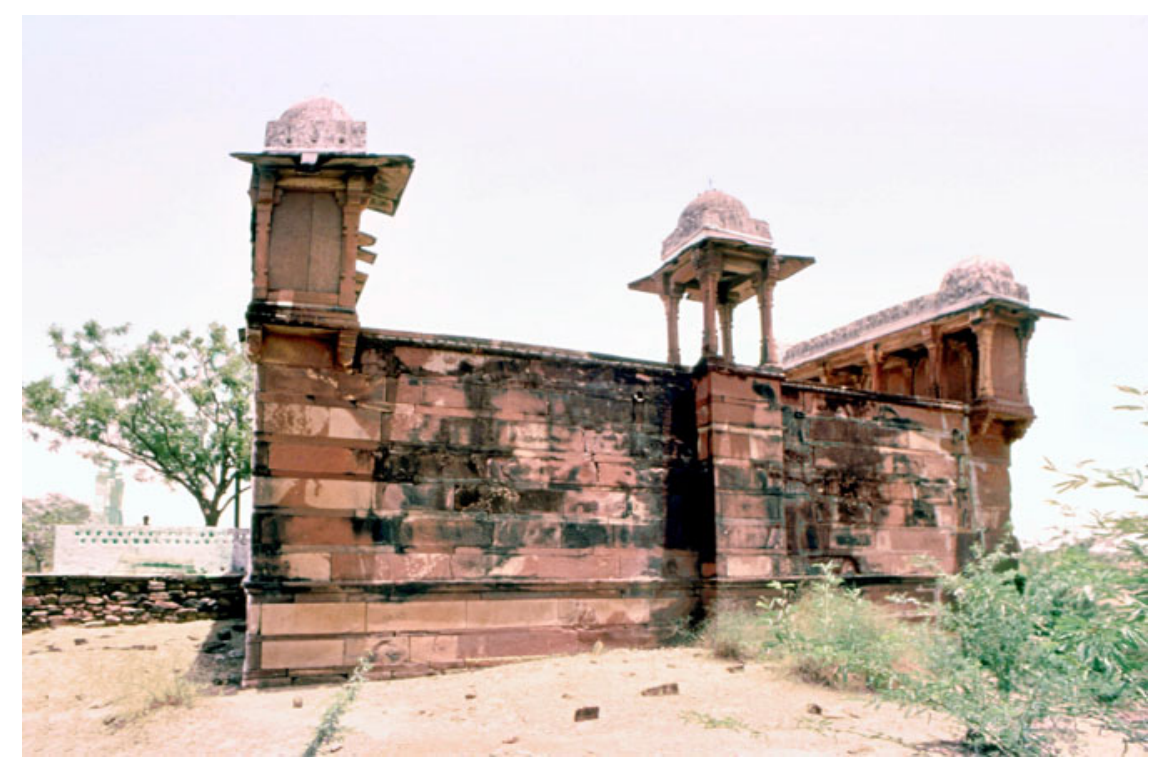

Figure 10. (Colour online) Mosque of Bībī Zarrīna, view from west. The solidity of the plain sandstone qibla wall of the mosque, and on the roof an arcade (which originally had $j \bar{a} l \bar{l} \mathrm{~s}$ ) and the chatriss, complement the lighter and more delicate tomb. Again the design is such that from the west the mosque appears as a massive structure and obscures the view of the tomb.

and geometric tracery in the field of the arches similar to that of the screens of the tomb. ${ }^{62}$ The delicate interlaced foliage pattern seen here is an elaborate variation of the spearhead fringes seen in many Muslim monuments in India as early as the fourteenth century. On the exterior only the central mihrāb projects outside the wall.

Within the northern and southern walls of the prayer hall are two staircases ascending to the roof, accessing two colonnades five bays wide and one aisle deep stretching the whole width of the hall. The backs of the colonnades are walled with light stone panels, those at each end carved as $j \bar{a} l \bar{l} \mathrm{~s}$, but some are broken and others replaced with plain panels. These colonnades, peculiar to this structure, are most unusual for the roof of a mosque and do not appear elsewhere. The buildings of the Bayana region often depart from the norm in form and function, and apart from the practical use of the roof as a place for the Caller to Prayer to recite the adhān, the colonnades would have provided a pleasant shady retreat. They also create a strong contrast to the tomb, but, again to harmonize the two buildings, four small domes punctuate the corners of the

62 The whitewash of the interior and highlighting the mihrābs with modern black paint has severely affected the original appearance of the features. The back of the central mihrāb has been painted in recent years with a crescent moon cradling a six-pointed star and the names of the Prophet and the three first Shiite Imāms (but omitting the names of the first three caliphs). Above the minbar these names are again painted on the pilaster of the wall, indicating that the mosque is now a place of worship for Shiites, whose presence in the Bayana region goes back many centuries. 


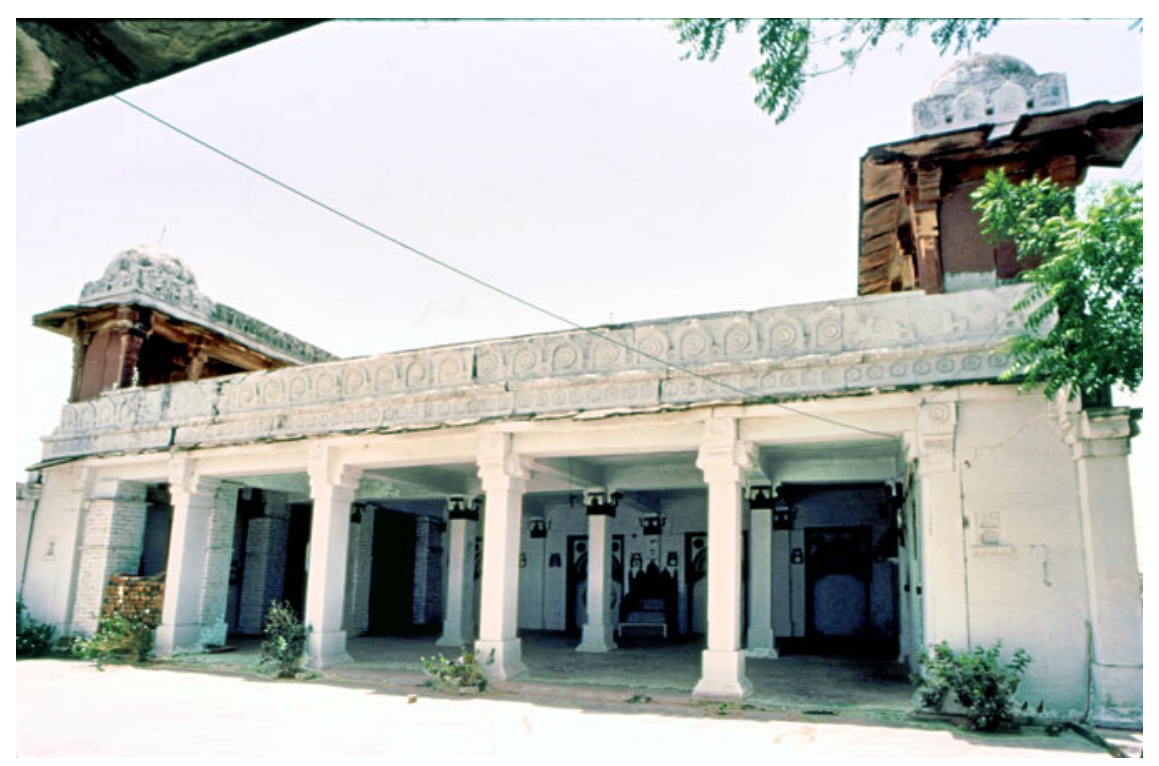

Figure 11. (Colour online) Mosque of Bībī Zarrīna, view from the courtyard looking west. The crenulations reflect the pattern of those of the tomb, but those above the front façade are carved on panels and those of the upper colonnades are each carved on a separate slab. The game of similarity and contrast between the tomb and the mosque is maintained in every detail.

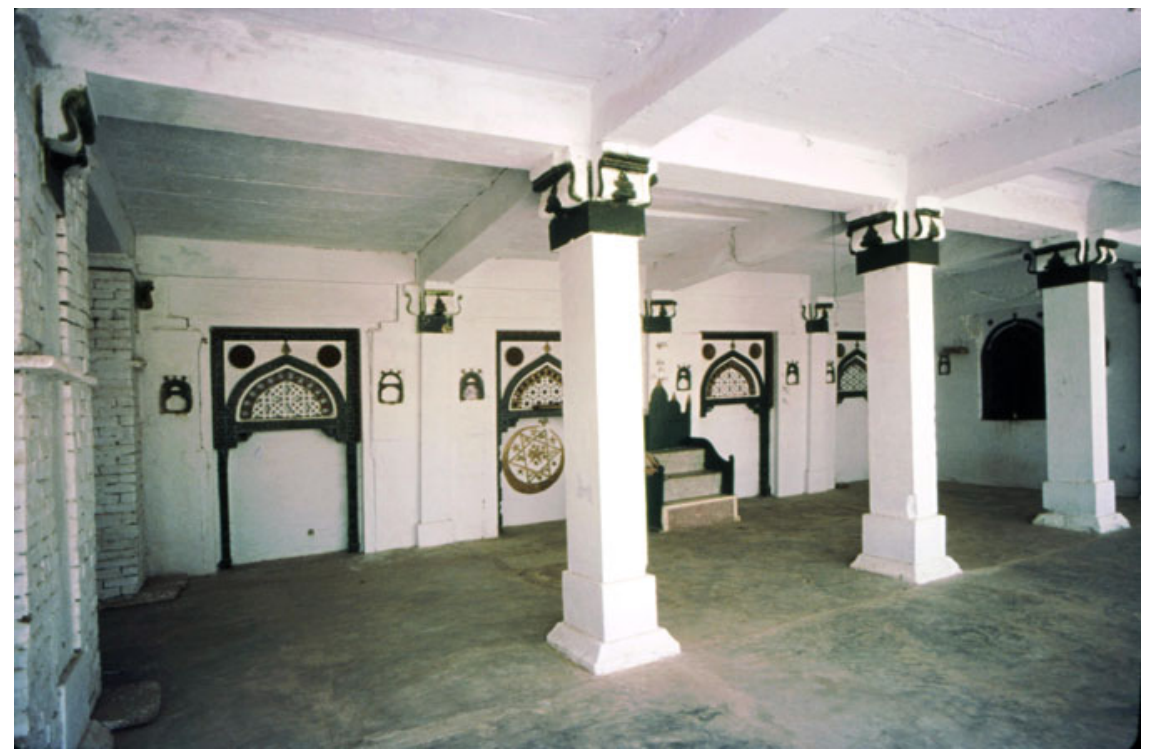

Figure 12. (Colour online) Mosque of Bībī Zarrīna, the prayer hall. The mihrāàs and lamp niches are carved to reflect the patterns of the screens of the tomb. The whitewash highlighted with black paint is modern, as is the painted calligraphy. 


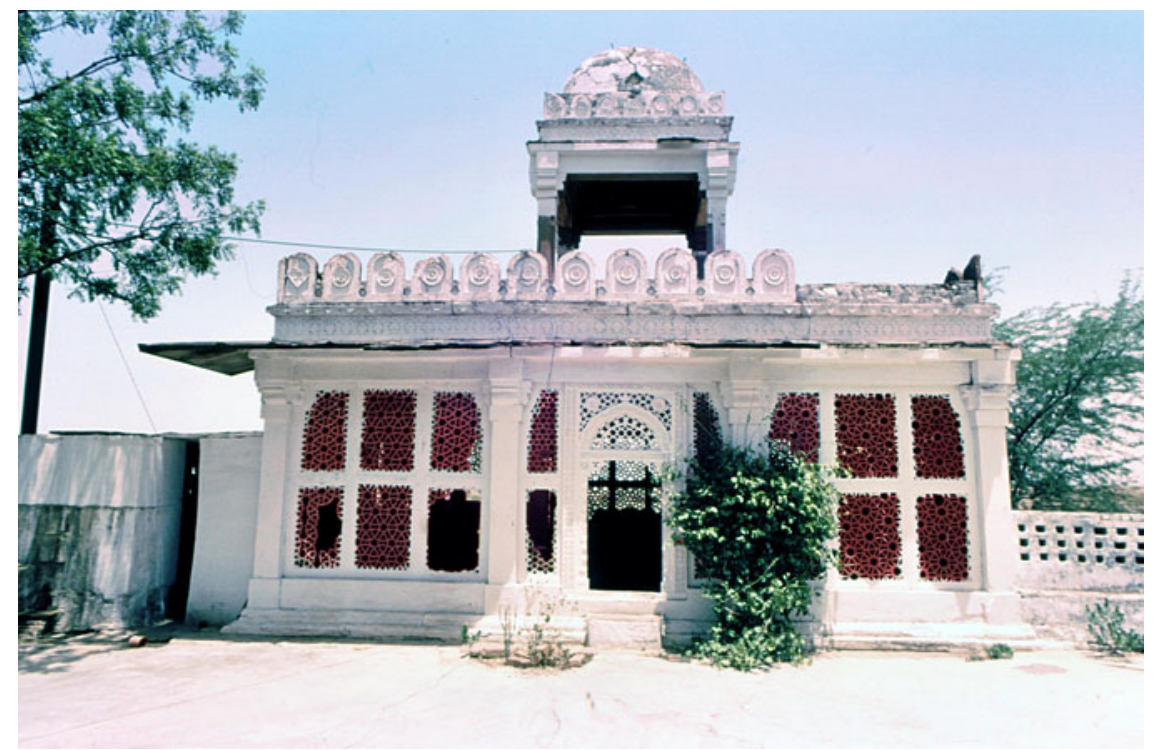

Figure 13. (Colour online) Tomb of Bībī Zarrīna, view from the courtyard looking east. The delicately carved red sandstone would have appeared like the carvings of a precious rosewood or sandalwood box.

composition, and a four-columned chatri is set over the projection of the central mihrāb.

The composition as a whole plays with contrast, leading the eye from one feature to another. The modest scale of the compound also seems intentional, as it suits the mother of a king, leaving the grander design for the tomb of the sultan himself. But there may have been another reason for the chosen scale. If the mausoleum were much larger it could not have been as light as it is and the balance between the size of the building and the finely carved screen work would have been lost. As it is, the chamber with its delicate $j \bar{a} l \bar{l}$ work (Figure 13) appears as an enlarged version of an ornamental box - a jewel box - of a type that used to be carved in ivory and are still fashioned in fine woods such as sandal; a suitable form, perhaps, for the daughter of a goldsmith, and within it the jewel - the mortal remains of the "Golden Bîbî̀". 